\title{
The Protection of Socio-Economic Rights through the Canon of Civil and Political Rights: A Comparative Perspective
}

Aristi Volou

DOI: $10.21827 / 5 a 6 a f 9 b d 48 d 3 a$

\author{
Keywords \\ SOCIO-ECONOMIC RIGHTS; INDIRECT PROTECTION; ECHR; ICCPR; RIGHT \\ TO LIFE
}

\begin{abstract}
Socio-economic rights have been largely neglected in international human rights law. Misconceptions about the nature of these rights have resulted in their marginalisation and their relegation to second-class rights. Effective enforcement mechanisms in respect of socio-economic rights are still lacking in international human rights law. In the context of the ICESCR, an individual complaint mechanism for socio-economic rights was only introduced in 2009. In contrast, civil and political rights have long been recognised in international human rights law and have always been subjected to effective enforcement mechanisms, in particular, individual complaint mechanisms. The distinction between the two sets of rights - civil and political rights on the one hand, and socio-economic rights on the other hand - has begun to fade. The international human rights community has now recognised the interdependence, indivisibility and interrelatedness of all human rights. Supervisory organs tasked with the interpretation and enforcement of civil and political rights treaties, most notably the ECtHR and the HRC, have played a crucial role in this process. They have recognised in their jurisprudence the interrelatedness of both sets of rights and have allowed socio-economic interests to be enforced indirectly through the canon of traditional, civil and political rights. This article specifically considers the ECtHR's and the HRC's jurisprudence on the right to life which demonstrates the extent to which these organs have protected social and economic interests. By using a variety of techniques, which are examined in this article, both organs have permeated the right to life with significant socio-economic dimensions. The analysis of the jurisprudence of the ECtHR shows that the right to life applies to cases concerning health interests in the broad sense as well as environmental interests. For its part, the HRC has not only recognised health and environmental interests as coming within Article 6 of the ICCPR, but also subsistence interests. The article concludes that, despite the conceptual developments, it is difficult for victims of such violations to succeed before the ECtHR and the HRC. The high standards imposed make it difficult for victims to bring successful claims based on the right to life.
\end{abstract}

PhD Candidate in Law and Teaching Assistant in Law, University of Leicester (av139@1e.ac.uk). I am grateful to Leicester Law School academics for providing comments on earlier drafts of this paper. Any remaining errors are those of the author. 


\section{Introduction}

The aim of this article is to investigate the extent to which socio-economic interests are protected under legal orders, which are primarily concerned with the protection of traditional, civil and political rights. The legal orders in question are the following: the European Court of Human Rights (ECtHR) and the European Convention on Human Rights (ECHR); as well as the UN Human Rights Committee (HRC) and the International Covenant on Civil and Political Rights (ICCPR). The two supervisory organs in question, the ECtHR and the HRC, have interpreted a number of civil and political rights as encompassing socio-economic elements. This article focuses on the dynamic interpretation of the right to life, which has come to cover a broad range of socio-economic interests. This article further examines the three techniques by which the ECtHR and the HRC have permeated civil and political rights with socio-economic interests. These include the interpretation of civil and political rights in the light of human dignity, the reading of positive obligations into civil and political rights, and the use of the 'integrated approach to interpretation'.

\section{The Three Techniques}

Although the ECHR was primarily intended to exclusively protect civil and political rights, the ECtHR has used two techniques to allow for some room for the protection of socio-economic interests under the ECHR. ${ }^{1}$ The ECtHR has interpreted civil and political rights in light of human dignity and, moreover, has read positive obligations into civil and political rights. ${ }^{2}$ The same techniques have been used by the HRC as demonstrated from the HRC's Concluding Observations and General Comments. ${ }^{3}$ The two bodies in question have also taken an integrated approach to the interpretation of civil and political rights. Although not mentioned explicitly in their judgments, General Comments or Concluding Observations, they have relied on this technique, which has enabled the two bodies to permeate civil and political rights with socio-economic elements. This section explores these techniques in more depth and illustrates their impact.

\section{A. The Interpretation of Civil and Political Rights in Light of Human Dignity}

The foundational value of human dignity began to enter the legal discourse in the first half of the $20^{\text {th }}$ century in a particularly sustained way. ${ }^{4}$ Nowadays, the value of human dignity has become commonplace in international human rights discourse. ${ }^{5}$ Human dignity, 'in the sense of referring to human dignity as inherent in Man', ${ }^{6}$ plays a crucial role in the protection of civil and political rights. It plays an equally crucial role in the protection of economic and social rights. The development of economic and social rights

O'Cinneide, O, "A Modest Proposal: Destitution, State Responsibility and the European Convention on Human Rights" 5 European Human Rights Law Review (2008) 583, 587.

2 Ibid.

3 See, for instance, UNHRC 'Comment on Israel's Third Periodic Report on Implementation of the ICCPR' (3 September 2010) UN Doc CCPR/C/ISR/CO/3, para 8; UNHRC 'Comment on Israel's Fourth Periodic Report on Implementation of the ICCPR' (21 November 2014) UN Doc CCPR/C/ISR/CO/4, para 12; UNHRC 'General Comment No.6' in 'Note by the Secretariat, Compilation of General Comments and General Recommendations adopted by Human Rights Treaty Bodies' (1982) UN Doc HRI/GEN/1/Rev.9, para 5.

4 McCrudden, C, "Human Dignity and Judicial Interpretation of Human Rights" 19 European Journal of International Law (2008) 655, 664.

5 Ibid, 668.

6 Ibid, 664. 
is seen as a key component of an equitable society and respect for human dignity. ${ }^{7}$ The development and protection of socio-economic rights is therefore largely attributed to the core value of respect for human dignity.

The use of the core value of human dignity is evident in the two systems of human rights protection in question. ${ }^{8}$ In relation to the ICCPR, its Preamble expressly refers to human dignity. ${ }^{9}$ It proclaims that: 'recognition of the inherent dignity... of all members of the human family is the foundation of freedom, justice and peace in the world', and the contention that 'rights derive from the inherent dignity of the human person'. ${ }^{10}$ In contrast, the ECHR does not make any reference to human dignity. Albeit not mentioned in the normative part of the ECHR, human dignity plays an important role in the ECHR system. ${ }^{11}$ As the ECtHR has repeatedly affirmed, "the very essence of the Convention is respect for human dignity'. ${ }^{12}$

As has been made clear, therefore, the ICCPR and the ECHR require an interpretation of their respective provisions, which upholds the core value of respect for human dignity. By interpreting the ICCPR's provisions in light of human dignity, the HRC has started to read a number of civil and political human rights provisions as imposing on States socio-economic obligations. ${ }^{13}$ Similarly, drawing on the core value of respect for human dignity, the ECtHR has identified socio-economic obligations in a number of ECHR provisions. ${ }^{14}$

\section{B. The Reading of Positive Obligations into Civil and Political Rights}

The obligations of States under international human rights law were traditionally negative in nature in the sense that States had an obligation not to interfere with the enjoyment of rights. ${ }^{15}$ 'Duties of restraint', as have been characterised by Fredman, are said to be 'determinate, immediately realisable, and resource free." ${ }^{16}$ The obligations of States under international human rights law were mainly obligations of restraint (negative obligations) rather than positive obligations, as the realisation of the latter was regarded as more difficult in several respects. First, positive obligations require States to proactively engage in activities. Second, they require the commitment of resources. Third, positive obligations are indeterminate in the sense that it is impossible to precisely define what a State has to do to fulfil the obligation. ${ }^{17}$ Due to the difficulties inherent in

7 Fredman, S, "Transformation or Dilution? Fundamental Rights in the EU Social Space" 12 European Law Journal (2006) 41, 44.

8 Perrone, R, "Public Morals and the European Convention on Human Rights" 47 Israel Law Review (2014) 361, 372.

9 International Covenant on Civil and Political Rights (adopted 16 December 1966, entered into force 23 March 1976) 999 UNTS 171 (ICCPR), Preamble.

10 Ibid.

11 Perrone, supra nt 8, 372-373.

12 See, for instance: Pretty $v$ the United Kingdom App no 2346/02 (ECtHR, 29 April 2002), para 65; Christine Goodwin v the United Kingdom App no 28957/95 (ECtHR, 11 July 2002), para 90.

13 See, for instance, UNHRC 'Comment on Israel's Third Periodic Report on Implementation of the ICCPR', supra nt 3, para 8; UNHRC 'Comment on Israel's Fourth Periodic Report on Implementation of the ICCPR', supra nt 3, para 12.

14 Palmer, E, Judicial Review, Socio-Economic Rights and the Human Rights Act (Hart Publishing 2007), 51. See, for instance, MSS v Belgium and Greece App no 30696/09 (ECtHR, 21 January 2011), para 263.

15 Mègret, F, "Nature of Obligations" in Moeckli, D, et al.,(eds), International Human Rights Law (Oxford University Press 2010), 130.

16 Fredman, S, Human Rights Transformed: Positive Rights and Positive Duties (Oxford University Press 2008), 70.

$17 \quad$ Ibid, ch 3. 
the realisation of positive obligations, the orthodoxy prevailed in international human rights law that the obligations of States were mainly obligations of restraint (negative obligations)..$^{18}$

However, certain international tribunals and monitoring bodies have long emphasised that States have also positive obligations. ${ }^{19}$ That the States have both negative and positive obligations has also been recognised by the ECtHR ${ }^{20}$ and the HRC. In relation to the ECHR system, the concept of positive obligations is derived from the text of the ECHR and in particular from Article $1,{ }^{21}$ which provides that: ' $[t]$ he High Contracting Parties shall secure to everyone within their jurisdiction the rights and freedoms defined in Section I of [the] Convention. ${ }^{22}$ This concept, however, did not make its appearance in the jurisprudence of the ECtHR until the late $1960 \mathrm{~s}^{23}$, when the ECtHR endorsed the view in the Belgian Linguistic case that the right to education as enshrined in Article 2 of Protocol 1 ECHR places a positive obligation on the Contracting States to ensure respect for the right in question. ${ }^{24}$ From the time of that remarkable decision, the ECtHR has constantly broadened this category with the addition of new elements 'to the point where virtually all the standard-setting provisions of the Convention now have a dual aspect in terms of their requirements, one negative and the other positive. ${ }^{25}$

Similarly, Article 2(1) ICCPR, the direct equivalent of Article 1 ECHR, imposes on States an obligation to respect and ensure the rights guaranteed by the ICCPR to all individuals within their territories and subject to their jurisdiction. ${ }^{26}$ When broken down, Article 2(1) ICCPR has both negative and positive components, 'in that it requires the [S] tate to respect the substantive provisions by refraining from unnecessary interference with them and ensure the rights by taking active steps domestically. ${ }^{27}$ The HRC expressly recognised in 2004 in its General Comment 31 that the legal obligation of States under Article 2(1) ICCPR is both negative and positive in nature. ${ }^{28}$ It has

18 White, R, and Ovey, C, The European Convention on Human Rights (5th ed, Oxford University Press 2010), 100.

19 Mègret, supra nt $15,131$.

20 For an extensive overview of the concept of positive obligations under the ECHR, see Mowbray, A, The Development of Positive Obligations under the European Convention on Human Rights by the European Court of Human Rights (Hart Publishing 2004); Xenos, D, The Positive Obligations of the State under the European Convention of Human Rights (Routledge 2012).

21 Singh, R, "Using Positive Obligations in Enforcing Convention Rights" 13 Judicial Review (2008) 94, 9495.

22 Convention for the Protection of Human Rights and Fundamental Freedoms (European Convention on Human Rights, as amended) (signed 4 November 1950, entered into force 3 September 1953) 213 UNTS 221 (ECHR), art 1 (emphasis added).

23 Akandji-Kombe, JF, Positive Obligations under the European Convention on Human Rights: $A$ Guide to the Implementation of the European Convention on Human Rights (Council of Europe 2007), 5.

24 Case 'relating to certain aspects of the laws on the use of languages in education in Belgium' $v$ Belgium App no 1474/62; 1677/62; 1691/62; 1769/63; 1994/63; 2126/64 (ECtHR, 23 July 1968) (Belgian Linguistic Case), 28.

25 Akandji-Kombe, supra nt 23, 5-6.

26 ICCPR, art 2(1).

27 Fottrell, D, "Reinforcing the Human Rights Act - The Role of the International Covenant on Civil and Political Rights" [2002] Public Law 485, 491.

28 UNHRC 'General Comment No.31' in 'Note by the Secretariat, Compilation of General Comments and General Recommendations adopted by Human Rights Treaty Bodies' (2004) UN Doc HRI/GEN/1/Rev.9, para 6. 
consistently reaffirmed the view that States have both negative and positive obligations in respect of all of the ICCPR's provisions. ${ }^{29}$

Given that positive obligations were traditionally associated with socio-economic rights, in contrast to negative obligations, which were associated with civil and political rights, ${ }^{30}$ the reading of positive obligations into civil and political rights can explain why the latter now have socio-economic dimensions. Indeed, as Joseph and Castan have observed, '[1]inked to the HRC's uncovering of positive aspects to civil and political rights has been its willingness to "permeate" ICCPR rights with significant economic, social, and cultural elements. ${ }^{31}$ In relation to the ECHR, this technique - to read positive obligations into civil and political rights - has opened up some room for the protection of socio-economic interests under the ECHR, as O'Cinneide has observed. ${ }^{32}$

\section{The Use of the 'Integrated Approach to Interpretation'}

The 'integrated approach to interpretation' is a technique, which has been used by various international tribunals and monitoring bodies, including the ECtHR and the $\mathrm{HRC}$, in order to give practical effect to the doctrine of interdependence of human rights. This technique has been used in order to relegate the dichotomy between civil and political rights on the one hand and socio-economic rights on the other, which is prominent in human rights law. The distinction between the two sets of rights is reflected in both systems of human rights protection. On the Council of Europe level, there are two distinct instruments of human rights protection: the ECHR, which is primarily concerned with civil and political rights, and the European Social Charter (ESC), which protects socio-economic rights. ${ }^{33}$ On the universal, United Nations (UN) level, the distinction between the two sets of rights is equally prominent. The ICCPR mainly protects civil and political rights whereas the International Covenant on Economic, Social and Cultural Rights (ICESCR) protects socio-economic rights. ${ }^{34}$ In their attempt to relegate this distinction, both bodies (the ECtHR and the HRC) have permeated civil and political rights with socio-economic elements. In other words, they have interpreted traditional civil and political rights in such a way so as to encompass socio-economic interests. ${ }^{35}$

This technique, the 'integrated approach to interpretation', is based on the 'permeability thesis'. ${ }^{36}$ The permeability thesis was developed on a theoretical or

29 Joseph, S and Castan, S, The International Covenant on Civil and Political Rights: Cases, Materials, and Commentary $\left(3^{\text {rd }}\right.$ ed, Oxford University Press 2013), 41.

30 Wiles, E, "Aspirational Principles or Enforceable Rights? The Future for Socio-Economic Rights in National Law" 22 American University International Law Review (2006) 35, 45.

31 Joseph and Castan, supra nt 29, 40. See also Scott, C, "The Interdependence and Permeability of Human Rights Norms: Towards a Partial Fusion of the International Covenants on Human Rights" 27 Osgoode Hall Law Journal (1989) 769, 876.

32 O'Cinneide, supra nt 1, 587.

33 European Social Charter (signed 18 October 1961, entered into force 26 February 1965) 529 UNTS 89 (ESC); European Social Charter (revised) (adopted 3 May 1996, entered into force 1 July 1999) 2151 UNTS 277 (RESC).

34 International Covenant on Economic, Social and Cultural Rights (adopted 16 December 1966, entered into force 3 January 1976) 993 UNTS 3 (ICESCR).

35 See Mantouvalou, V, "Labour Rights in the European Convention on Human Rights: An Intellectual Justification for an Integarated Approach to Interpretation" 13 Human Rights Law Review (2013) 529, 555; Scott, supra nt 31.

36 Mantouvalou, Ibid, 545. 
philosophical level by Scott in $1989 .{ }^{37}$ In his seminal piece 'The Interdependence and Permeability of Human Rights Norms: Towards a Partial Fusion of the International Covenants on Human Rights', Scott emphasised the interdependence of human rights and proposed permeability as a means to give practical effect to the abstract doctrine of interdependence of human rights. ${ }^{38}$ Referring to the ICCPR and the ICESCR, Scott urged the HRC to "break down the artificial separation of the two leading universal human rights instruments by means of a permeability presumption. ${ }^{39}$ Permeability was more specifically described as the 'openness of a treaty dealing with one category of human rights to having its norms used as vehicles for the direct or indirect protection of norms of another treaty dealing with a different category of human rights. ${ }^{40}$

More recently, the permeability thesis has been put into practice by international human rights tribunals and monitoring bodies as they have interpreted traditional protections in the form of civil and political rights in a manner that encompasses violations traditionally considered to be of an economic and social nature. ${ }^{41}$ Scott's permeability thesis has more recently come to be known as the 'integrated approach to interpretation'. ${ }^{42}$ It is an integrated approach, as Mantouvalou has observed, 'because it integrates certain socio-economic rights into a civil and political rights document. ${ }^{43}$ The integrated approach to interpretation is now commonplace in human rights law.

Although the ECHR and the ICCPR set forth mainly civil and political rights, their respective bodies have declared that the two categories of rights are interdependent and interrelated. In this way, they have clarified that there is scope for the protection of socio-economic rights under the two instruments. As long ago as Airey $v$ Ireland, the ECtHR recognised that there is no 'water-tight division' separating civil and political rights from economic and social rights, and the fact that ECHR rights have a social dimension should not of itself be a barrier to justiciability. ${ }^{44}$ Similarly, the HRC has made clear in a number of General Comments and Concluding Observations that certain ICCPR provisions have socio-economic dimensions. ${ }^{45}$

The use of the integrated approach to the interpretation of civil and political rights has significant implications. This interpretative technique, as Mantouvalou has observed, has made socio-economic rights indirectly effective in jurisdictions and systems that do

37 Scott, supra nt 31. See, also, Scott, C, "Reaching Beyond (Without Abandoning) the Category of Economic, Social and Cultural Rights" 21 Human Rights Quarterly (1999) 633, 660.

38 Ibid, 778.

39 Ibid, 771.

40 Ibid, 771.

41 Foster, M, International Refugee Law and Socio-Economic Rights: Refuge from Deprivation (Cambridge University Press 2007), 181.

42 Mantouvalou, V, "Work and Private Life: Sidabras and Dziautas v Lithuania" 30 European Law Review (2005) 573, 574. It has been also called 'holistic approach', see, Leary, VA, "Lessons from the Experience of the International Labour Organisation" in Alston, P, (ed), The United Nations and Human Rights: A Critical Reappraisal (Oxford University Press 1992), 590.

43 Mantouvalou, supra nt 35, 536.

44 Airey v Ireland App no 6289/73 (ECtHR, 9 October 1979), para 26.

45 See, for instance, UNHRC 'General Comment No.6', supra nt 3, para 5; UNHRC 'General Comment No.14' in 'Note by the Secretariat, Compilation of General Comments and General Recommendations adopted by Human Rights Treaty Bodies' (1984) UN Doc HRI/GEN/1/Rev.9, para 3; UNHRC 'General Comment No.28' in 'Note by the Secretariat, Compilation of General Comments and General Recommendations adopted by Human Rights Treaty Bodies' (2000) UN Doc HRI/GEN/1/Rev.9, paras 10, 28; UNHRC 'General Comment No. 31', supra nt 28, para 6; UNHRC 'Comment on Canada's Fourth Periodic Report on Implementation of the ICCPR' (7 April 1999) UN Doc CCPR/C/79/Add.105, para 12. 
not grant them direct legal effect, like the two systems in question. ${ }^{46}$ This is certainly a significant development regarding the fate of socio-economic rights. Socio-economic rights are now protected, albeit indirectly and only to a certain extent, through the ECHR and the ICCPR. However, we should not deduce from this that the ECHR or the ICCPR can now stand-in for an effective set of socio-economic rights. In other words, this does not mean that all socio-economic rights are fully protected under the legal orders in question. What it does mean, however, is that some avenues have now opened up for the protection of certain socio-economic interests under the legal orders in question. To determine the extent to which socio-economic interests are protected under the legal orders in question, a deep analysis and examination of the jurisprudence of the ECtHR and the HRC on the right to life is carried out in the following section.

\section{The Protection of Socio-Economic Interests Through the Right to Life}

By using the three techniques discussed above, both the ECtHR and the HRC have extended the protection of their respective instruments to cover socio-economic interests. This section examines the extent to which such interests are protected under the legal orders in question, and more specifically under the right to life, by analysing the relevant jurisprudence of the ECtHR and the HRC. It will begin with an analysis of the jurisprudence of the ECtHR, illustrating which socio-economic interests have been protected through the right to life, along with the level of protection accorded in these cases. The same approach will be adopted with respect to the HRC's approach to the ICCPR in the subsequent section.

\section{A. The ECHR}

The right to life is guaranteed under Article 2 of the ECHR. ${ }^{47}$ The Strasbourg organs (the ECtHR and the European Commission of Human Rights) have read positive obligations into Article 2 ECHR and this has been decisive regarding the protection of socioeconomic interests under the provision in question. In other words, it is for that reason that Article 2 ECHR encompasses social and economic interests. The first technique discussed in this article - the interpretation of civil and political rights in the light of human dignity - has been of no use in this context. The ECtHR has not been willing to interpret Article 2 ECHR in this manner, as illustrated below. This has had significant implications regarding the protection of socio-economic interests under Article 2 ECHR. Given that Article 2 ECHR has been permeated with socio-economic elements, as demonstrated in this subsection, it follows that the integrated approach to interpretation has been used in this context.

The possibility that the Strasbourg organs might be prepared to fashion a positive social right from Article 2 ECHR flourished between 1976 and 1978 as a result of the European Commission of Human Rights' decisions on two public health cases. ${ }^{48}$ In the first case, $X v$ Ireland, which concerned a claim that the applicants' daughter had not been allowed free medical treatment by the State, the European Commission of Human Rights accepted that Article 2 ECHR was engaged. ${ }^{49}$ It declared the application inadmissible, however, on grounds that she had in fact received some medical care, and her life had

46 Gearty, C, and Mantouvalou, V, Debating Social Rights (Hart Publishing 2011), 114.

47 ECHR, art 2.

48 Palmer, supra nt 14, 67. Xv Ireland (1976) 7 DR 78 (X); Association Xv the United Kingdom (1978) 14 DR 31 (Association X).

${ }^{49} X v$ Ireland, Ibid. 
not been put at risk. ${ }^{50}$ In the second case, Association $X v$ the United Kingdom, which involved the administration of a voluntary vaccination scheme in which many children died, the European Commission of Human Rights declared the application inadmissible on the ground that appropriate steps had been taken for the safe administration of the scheme in question. ${ }^{51}$

These decisions are significant because the European Commission of Human Rights accepted that Article 2 ECHR was engaged in this context. More importantly, it declared that Article 2(1) ECHR enjoins a Contracting State not only to refrain from taking life intentionally but also to safeguard life. ${ }^{52}$ By reading positive obligations into Article 2 ECHR, the European Commission of Human Rights opened up some room for the protection of socio-economic interests, and in particular health interests, under the provision in question. In other words, the European Commission of Human Rights clarified that Article 2 ECHR might be applicable in cases which concern health interests.

In 1998, in their concurring opinions in the case of Guerra and others $v$ Italy, which concerned a claim that the State authorities had not taken appropriate action to reduce the risk of pollution by a chemical factory and to avoid the risk of major accidents, Judges Walsh and Jambrek expressed the view that the protection of health and physical integrity was closely associated with Article 2 ECHR. ${ }^{53}$ This encouraged further expectations that the right to life might be furnished in such a way so as to apply in scenarios, which concern socio-economic interests, and in particular health interests. ${ }^{54}$ Given that the ECtHR in the case of Guerra concluded that there had been a violation of Article $8 \mathrm{ECHR}$, it found it unnecessary to also consider the case under Article 2 ECHR. ${ }^{55}$

The ECtHR unanimously accepted that Article 2 ECHR might protect social interests in the case of $L C B v$ the United Kingdom, which involved a claim that the failure of the State to warn the applicant's parents of the possible risk to her health caused by her father's exposure to environmental hazards, and the State's failure to monitor her health in light of those hazards, constituted a breach of Article 2 ECHR. ${ }^{56}$ The ECtHR unanimously agreed that Article $2 \mathrm{ECHR}$ was engaged, ${ }^{57}$ therefore expressing the view that Article 2 ECHR might protect social interests and in particular environmental and health interests. It confirmed that States have an obligation under Article 2(1) ECHR to safeguard the lives of those within their jurisdiction. However, in this case it was concluded that there had been no violation of Article 2 ECHR due to the limited information about the risks to the applicant's health available to the State at the relevant time. ${ }^{58}$ This case is of particular importance as it demonstrates that the ECtHR has permeated Article 2 ECHR with socio-economic components. In addition, this case is

Ibid.

1 Association $X v$ the United Kingdom, supra nt 48.

$52 X$, supra nt 48 , para 32. For a discussion of the case $X v$ Ireland, see, O'Sullivan, D, "The Allocation of Scarce Resources and the Right to Life under the European Convention on Human Rights" [1998] Public Law 389, 391-393.

53 Guerra and others $v$ Italy App no 116/1996/735/932 (ECtHR, 19 February 1998), concurring opinions of Judges Walsh and Jambrek. See, also, Vilnes and others $v$ Norway Apps nos 52806/09 and 22703/10 (ECtHR, 5 December 2013), para 245.

54 See, for instance, Edwards, RA, and Billings, P, "Safeguarding Asylum Seekers' Dignity: Clarifying the Interface between Convention Rights and Asylum Law" 11 Journal of Social Security Law (2004) 83, 102.

55 Guerra and others $v$ Italy, supra nt 53, para 62.

56 LCB v the United Kingdom App no 14/1997/798/1001 (ECtHR, 9 June 1998).

57 Ibid, para 36.

58 Ibid, paras 36, 41. 
significant because it demonstrates that the protection of socio-economic interests under Article 2 ECHR largely results from the ECtHR's use of the second technique - the reading of positive obligations into civil and political rights.

Following $L C B$, in the case of Osman v the United Kingdom, the ECtHR established the far-reaching principle that 'it is sufficient for an applicant to show that the authorities did not do all that could be reasonably expected of them to avoid a real and immediate risk to life of which they have or ought to have knowledge. ${ }^{59}$ The ECtHR, however, emphasised that the positive obligations flowing from Article 2 ECHR should be interpreted 'in a way which does not impose an impossible or disproportionate burden on the authorities' ${ }^{60}$ Even though Osman case was not raising socio-economic rights, the reasoning of the ECtHR in this case has been applied in cases, which did concern socioeconomic interests. The ECtHR's ruling in Osman, as Palmer has observed, 'raised further expectations that the positive aspect of Article 2 might be used to hold public authorities to account for failure to provide appropriate health services. ${ }^{61}$

In Erikson $v$ Italy and in Calvelli and Ciglio v Italy, the ECtHR laid down two important principles, which guide its current approach to Article 2 ECHR. ${ }^{62}$ The former case, which was decided in 1999, concerned a complaint that the right to life of the applicant's mother was violated on account of the failure of the Italian authorities to exercise their best efforts to identify those responsible for her death. In this case, the ECtHR read into Article 2 ECHR 'the requirement for hospitals to have regulations for the protection of their patients' lives' ${ }^{63}$ The latter case, which was decided in 2002, concerned a complaint under Article 2 ECHR that, owing to procedural delays, a timebar had arisen making it impossible to prosecute the doctor responsible for the delivery of the applicants' child, who had died shortly after birth. In Calvelli, the ECtHR held that the positive obligations of States under Article 2 ECHR 'require States to make regulations compelling hospitals, whether public or private, to adopt appropriate measures for the protection of their patients' lives. ${ }^{, 64}$ Through this decision, the ECtHR extended the obligation of States under Article 2 ECHR to the regulation of private sector medical treatment providers.

Despite the promise of Erikson v Italy and Calvelli and Ciglio v Italy, as well as the cases discussed above, applicants have only in rare occasions succeeded in invoking Article 2 ECHR or in convincing the ECtHR that there had been a violation of the provision in question. By examining a wide range of cases, it will be demonstrated that this is the case in relation to Article 2 ECHR. The cases that will be examined below are those, which demonstrate the range of socio-economic interests that have been protected through the right to life. For clarity purposes, they are categorised in terms of themes: medical negligence or malpractice (a.), funding for treatment (b.), health treatment and level of health-care (c.), destitution (d.), subsistence provision (e.), and environmental interests (f.).

59 Osman $v$ the United Kingdom App no 87/1997/871/1083 (ECtHR, 28 October 1998), para 116.

60 Ibid.

61 Palmer, supra nt 14, 68.

62 Erikson v Italy (dec) App no 37900/97 (ECtHR, 26 October 1999); Calvelli and Ciglio v Italy App no 32967/96 (ECtHR, 17 January 2002).

63 Erikson v Italy, Ibid.

64 Calvelli and Ciglio v Italy, supra nt 62, para 49. See, also, Vo v France App no 53924/00 (ECtHR, 8 July 2004), para 89. 


\section{i. Medical Negligence or Malpractice}

In the case of Powell v the United Kingdom, which concerned a boy who died due to failure to diagnose his curable disease in time, the ECtHR recalled that States have an obligation under Article 2 ECHR to take appropriate steps to safeguard life. ${ }^{65}$ Even though the ECtHR did not exclude that 'the acts and omissions of the authorities in the field of health care policy may in certain circumstances engage their responsibility under the positive limb of Article 2', it declared the claim inadmissible. ${ }^{66}$ The ECtHR emphasised that:

'where a Contracting State has made adequate provision for securing high professional standards among health professionals and the protection of the lives of patients, it cannot accept that matters such as error of judgment on the part of a health professional or negligent co-ordination among health professionals in the treatment of a particular patient are sufficient of themselves to call a Contracting State to account from the standpoint of its positive obligations under Article 2 ECHR to protect life. ${ }^{67}$

This decision makes it undoubtedly more difficult for individual applicants to succeed as it confirms that mere negligence on the part of the health authorities in an individual case will not be sufficient to call a Contracting State to account from the standpoint of its positive obligations under Article 2 ECHR. However, this decision is justified. The ECtHR could reach no other conclusion as 'not every claimed risk to life can entail for the authorities a Convention requirement to take operational measures to prevent that risk from materialising. ${ }^{68}$

In a series of more recent cases, the ECtHR found violations of Article 2 ECHR, with the exception of $G N$ and others $v$ Italy. ${ }^{69}$ This case concerned the infection of the applicants and their relatives with HIV or hepatitis $C$ following blood transfusions carried out by the health authorities of the State. The ECtHR held that there had been no breach of Article 2 ECHR regarding the obligation to protect the lives of the applicants and their relatives. ${ }^{70}$ The ECtHR observed in particular that it had not been established that at the material time, the Ministry of Health had known or should have known about the risk of transmission of HIV or hepatitis $\mathrm{C}$ via blood transfusion, and that it could not determine from what dates onward the Ministry had been or should have been aware of the risk. ${ }^{71}$

The case of Oyal v Turkey involved the State's failure to provide a patient with full and free medical cover for life, following his infection with the HIV virus due to the failure of the national authorities to sufficiently train, supervise and inspect the work of the medical staff involved in the applicant's blood transfusions. ${ }^{72}$ In this case, the ECtHR held that there had been a violation of Article $2 \mathrm{ECHR} .{ }^{73}$ It noted that the redress offered to the applicant and his parents had been far from satisfactory for the purposes of the

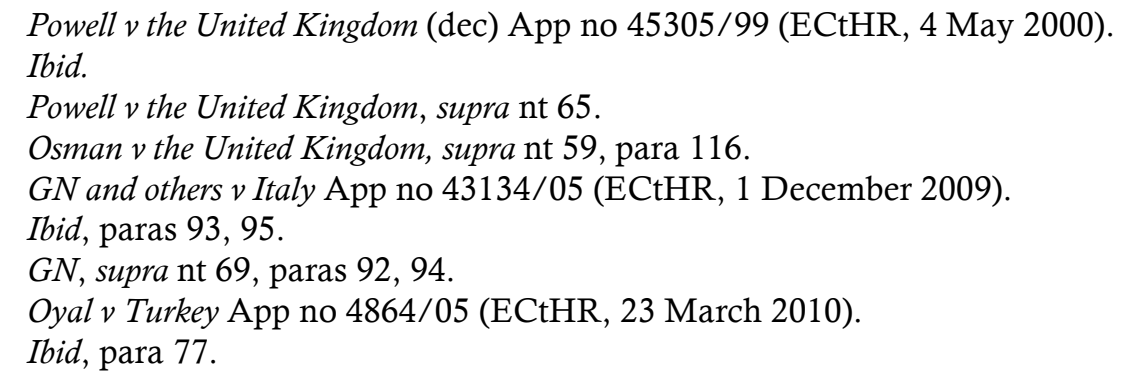


positive obligation under Article 2 ECHR.$^{74}$ The State could have discharged its positive obligation under Article 2 ECHR by paying for the applicant's treatment and medication expenses during his lifetime. ${ }^{75}$

In Mehmet SSentürk and Bekir Şentürk $v$ Turkey, the negligence of the medical staff caused the death of the applicants' pregnant mother and wife. ${ }^{76}$ The ECtHR held that the State had failed in its obligation to protect the physical integrity of the deceased. ${ }^{77}$ The ECtHR found, in particular, that the deceased had been a victim of a 'flagrant malfunctioning of the hospital departments', and that she had been denied the possibility of access to appropriate emergency treatment. ${ }^{78}$ In Asiye Genç v Turkey, the ECtHR was called upon to ascertain whether the national authorities had done what could have been reasonably expected of them to prevent a baby's death and, in particular, whether they had satisfied their obligation to adopt measures to ensure the protection of the baby's life..$^{79}$ This case concerned a prematurely born baby's death in an ambulance, a few hours after birth, following the baby's transfer between hospitals without being admitted for treatment. The ECtHR found a breach of Article 2 ECHR ${ }^{80}$ It found, in particular, that the State had not sufficiently ensured the functioning and proper organisation of the public hospital service or its health protection system. ${ }^{81}$ It noted that the baby died because it had not been offered any treatment and the ECtHR observed that such a situation constituted a denial of medical care such as to put a person's life at risk. ${ }^{82}$

These decisions demonstrate that in cases of medical negligence or malpractice, the positive limb of Article 2 ECHR will be violated in particular circumstances. As evidenced by its case law, the ECtHR will find a violation of the right to life in such cases only if the person concerned was a victim of a malfunctioning of the health-care system resulting in the endangerment of his or her life. This distinguishes these cases from the case of Powell. In contrast to these cases, no issue arose as to the functioning of the health-care system in Powell. Instead, the ECtHR highlighted that the event in question (the death of the child) had been the result of an error in an individual case. What should be proved, therefore, is that the person concerned was a victim of a more general situation, which had resulted in his or her life being put at risk. Thus, a mere negligence on the part of the health authorities in a single case will not be sufficient for a finding of a breach of Article 2 ECHR.

\section{ii. Funding for Treatment}

In the case of Nitecki $v$ Poland, the applicant complained that the refusal of the State to refund the full price of a life-saving drug violated his right to life under Article $2 \mathrm{ECHR} .{ }^{83}$ The ECtHR emphasised that '[i]t cannot be excluded that the acts and omissions of the authorities in the field of health care policy may in certain circumstances engage their

Oyalv Turkey, supra nt 72, para 72.

Ibid.

76 Mehmet Şentürk and Bekir Şentürk v Turkey App no 13423/09 (ECtHR, 9 April 2013).

Ibid, para 97.

78 Şentürk, supra nt 76, para 97.

79 Asiye Gençv Turkey App no 24109/07 (ECtHR, 27 January 2015), para 75.

$80 \quad$ Ibid, para 87.

81 Asiye Gençv Turkey, supra nt 79, para 82.

82 Ibid.

83 Nitecki v Poland (dec) App no 65653/01 (ECtHR, 21 March 2002). For an analysis of the cases on public-funded treatment under Article 2 ECHR, see, Brems, E, "Indirect Protection of Social Rights by the European Court of Human Rights" in Barak-Erez, D, and Gross, AM, (eds), Exploring Social Rights: Between Theory and Practice (Hart Publishing 2007), 146-147. 
responsibility under Article 2'. ${ }^{84}$ As Koch has observed, the ECtHR would not entirely rule out that the right to a life-saving drug might be protected under Article 2 ECHR. ${ }^{85}$ The ECtHR, however, declared the application inadmissible. ${ }^{86}$ According to the ECtHR, the State discharged its positive obligations under Article 2 ECHR by refunding $70 \%$ of the cost of the drug. ${ }^{87}$ Similarly, in Wiater $v$ Poland, the applicant complained that the refusal of the authorities to reimburse the cost of a drug amounted to a violation of Article 2 ECHR ${ }^{88}$ The ECtHR declared the application inadmissible. ${ }^{89}$ The State's refusal to refund the cost of the drugs in the cases of Nitecki and Wiater resulted in the applicants' inability to follow a prescribed pharmaceutical treatment. ${ }^{90}$

In another example, Pentiacova and others $v$ Moldova, the applicants complained about the failure of the State to cover the cost of all the medication necessary for their haemodialysis, and about the poor financing of the haemodialysis section of the hospital. ${ }^{91}$ The ECtHR stated that the applicants had failed to adduce evidence that their lives had been put at risk, arguing,

'[w] hile it is clearly desirable that everyone should have access to a full range of medical treatment, including life-saving medical procedures and drugs, the lack of resources means that there are, unfortunately, in the Contracting States many individuals who do not enjoy them, especially in cases of permanent and expensive treatment. ${ }^{, 92}$

Accordingly, the ECtHR declared the application inadmissible. ${ }^{93}$

What emerges from the ECtHR's approach in these cases is that States do not have a positive obligation under Article 2 ECHR to pay for a particular form of treatment. In addition, as McBride has explained, '[a]lthough it is clear that there is a very substantial duty to protect life, it is also evident that this is not one that is to be fulfilled regardless of all other considerations. ${ }^{, 94}$ As it is clear from these cases, budgetary considerations do play a role in the ECtHR's decisions. Article 2 ECHR might protect the right to treatment but the case law of the ECtHR reflects the crucial reality that, 'when imposing positive obligations upon state authorities, there must be recognition of the need to balance conflicting demands upon the public purse. ${ }^{95}$ In Wiater, the ECtHR emphasised that an applicant cannot lay claim to public funds in order to be treated with a particular drug and that it is for the competent authorities of the Contracting States to consider and decide how their limited resources should be allocated in the field of health-

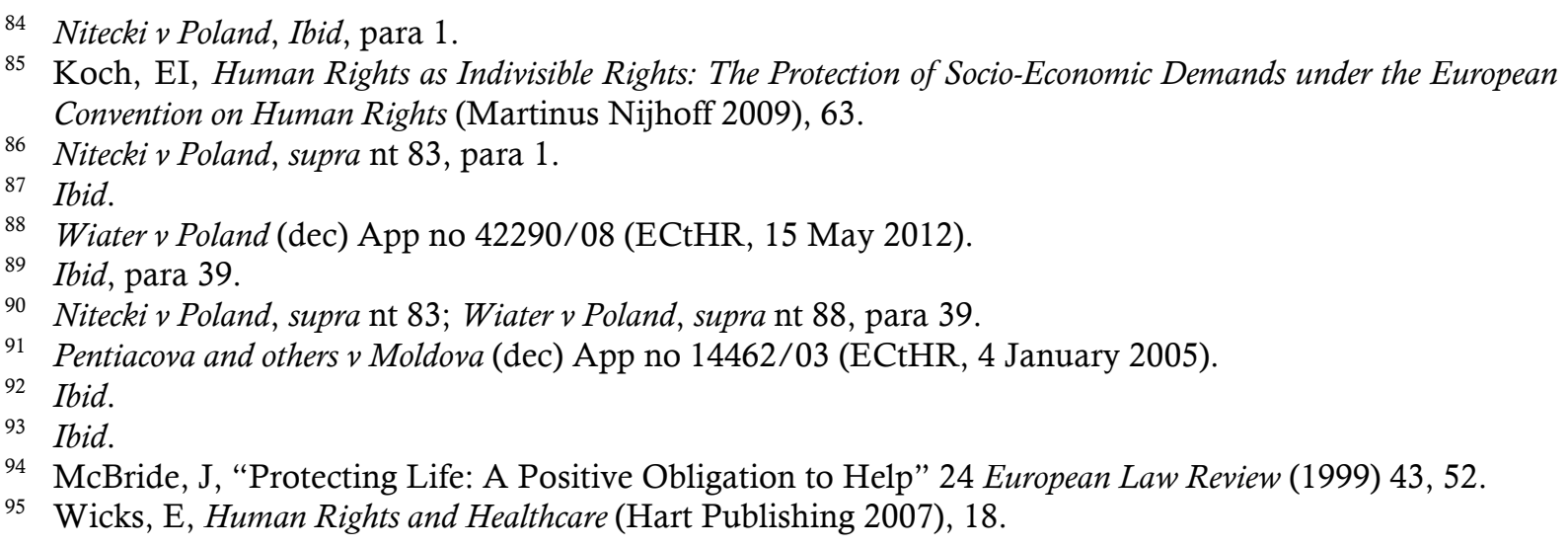


care. ${ }^{96}$ It does not, however, follow that lack of resources can always be used as a defence to such claims ${ }^{97}$ or that budgetary considerations will always be decisive.

In Oyal, for instance, the ECtHR held that the State should have provided the applicant with full and free medical cover for life. This decision demonstrates that the right to treatment, including the right to publicly funded treatment, might be protected under Article 2 ECHR. The ECtHR's conclusion in Oyal was different in comparison with the cases of Nitecki, Wiater and Pentiacova on the ground that in the former case, the applicant's life had been endangered (through infection with the HIV virus) as a result of the State's inaction (due to the failure of the national authorities to sufficiently train, supervise and inspect the work of the medical staff involved in the applicant's blood transfusions). Since the respective States were not responsible for the applicants' illness in the Nitecki, Wiater and Pentiacova cases, the States had no obligation to fund their treatment. In cases that concern funding for treatment from the State, applicants will succeed before the ECtHR only if the State is responsible for their situation. Once again, therefore, State responsibility becomes decisive.

\section{iii. Health Treatment - Level of Health-Care}

In the inter-State case of Cyprus $v$ Turkey, the applicant Government claimed that Greek Cypriots and Maronites residing in the northern part of Cyprus were denied the right to avail themselves of health-care services in the southern part of Cyprus, and that the health-care facilities in the north were inadequate. ${ }^{98}$ The ECtHR emphasised that 'an issue may arise under Article 2 of the Convention where it is shown that the authorities of a Contracting State put an individual's life at risk through the denial of health care which they have undertaken to make available to the population generally. ${ }^{99}$ The ECtHR, however, held that there had been no breach of Article 2 ECHR. ${ }^{100}$ It took note of the fact that the European Commission of Human Rights had not been able to establish that the Turkish authorities (the 'TRNC' authorities) 'deliberately withheld medical treatment from the population concerned or adopted a practice of delaying the processing of requests of patients to receive medical treatment in the south. ${ }^{101}$ Although the ECtHR acknowledged that medical visits were indeed hampered due to restrictions imposed by the 'TRNC' authorities, and that delays did in fact occur, it found that it had not been established that the lives of any patients were put at risk on account of delays in individual cases. ${ }^{102}$ The ECtHR also attached importance to the fact that Greek Cypriots and Maronites could avail themselves of medical services in the north. ${ }^{103}$

As to the applicant Government's critique of the level of health-care available in the north, the ECtHR did not consider it 'necessary to examine in this case the extent to which Article 2 of the Convention may impose an obligation on a Contracting State to make available a certain standard of health care. ${ }^{, 104}$ It is clear, therefore, that in this case the ECtHR was unwilling to define in positive terms the content of a minimum core

96 Wiater $v$ Poland, supra nt 88, para 39.

97 Havers, P, "The Impact of the European Convention on Human Rights on Medical Law" 70 MedicoLegal Journal (2002).

98 Cyprus v Turkey App no 25781/94 (ECtHR, 10 May 2001).

99 Ibid, para 219.

${ }^{100} \mathrm{Ibid}$, para 221.

${ }^{101} \mathrm{Ibid}$, para 219.

${ }^{102}$ Ibid.

${ }^{103}$ Ibid, para 219.

${ }^{104}$ Ibid. 
right. This decision is significant because it clarifies that, at least for the time being, it is left up to the Contracting States to define their own level of health-care provision. ${ }^{105}$ The ECtHR, however, might be willing to undertake such an examination, which is undoubtedly a very difficult one, ${ }^{106}$ under different circumstances, as Koch has observed. ${ }^{107}$ This can be inferred from the ECtHR's use of the term 'necessary'. ${ }^{108}$ In addition, in this case, the ECtHR could have defined at least in negative terms what level of health-care it considered to be inadequate under Article 2 ECHR, given that in cases which concerned detention conditions, the Court stated in negative terms what level it considered to be unacceptable under Article 3 ECHR (the prohibition of degrading treatment). ${ }^{109}$

\section{iv. Destitution}

As has been made clear, there is no requirement flowing from Article 2 ECHR to provide a particular type or level of health-care. Nevertheless, the ECtHR has recognised that acts and omissions by State authorities in the field of health-care, which expose individuals to threats to their lives, might in certain circumstances engage their responsibility under Article 2 ECHR. O'Cinneide has argued that the responsibility of States under Article 2 ECHR might be also engaged in cases which concern threats to life which stem from lack of shelter. ${ }^{110}$ According to him, the true potential of Article 2 ECHR in this context is best suggested in Öneryildiz $v$ Turkey. ${ }^{111}$ This case concerned the failure of administrative authorities to take action to protect slum-dwellers, who were living near a rubbish tip, from the threat of a methane gas explosion. The failure of the authorities was held to constitute a violation of the right to life of the applicant's nine relatives, who died when the explosion eventually occurred. ${ }^{112}$ The ECtHR noted that the State authorities had not done 'everything within their power to protect them from the immediate and known risks to which they were exposed.'113

Even though in the case of Öneryildiz the threat to life did not directly stem from the destitute status of the slum-dwellers, but more indirectly from their residence in a hazardous area,

'it would involve no great conceptual leap to suggest that [S]tate responsibility may be engaged where state action or inaction exposes the destitute to...threats to their life where the nature and existence of that...threat should have been known to the authorities and reasonable remedial action could have been taken to avoid it. ${ }^{114}$

\footnotetext{
${ }^{105}$ Mowbray, A, Cases, Materials, and Commentary on the European Convention on Human Rights (3rd ed, Oxford University Press 2012), 125.

106 Chapman, AR, "Core Obligations Related to the Right to Health" in Chapman, A, and Russell, S, Core Obligations: Building a Framework for Economic, Social and Cultural Rights (Intersentia 2002), 188.

107 Koch, supra nt 85, 64.

108 Ibid.

109 Koch, supra nt 85, 64. See, for instance, Khokhlich v Ukraine App no 41707/98 (ECtHR, 29 April 2003), para 181; Kuznetsov v Ukraine App no 39042/97 (ECtHR, 29 April 2003), para 128; Poltoratskiy v Ukraine App no 38812/97 (ECtHR, 29 April 2003), para 148.

110 O'Cinneide, supra nt 1, 590.

111 Ibid; See, Öneryildiz v Turkey App no 48939/99 (ECtHR, 30 November 2004).

112 Öneryildiz, Ibid, paras 109-110.

113 Ibid, para 109.

114 O'Cinneide, supra nt 1, 590.
} 
According to O'Cinneide, therefore, States might be under a responsibility in particular circumstances to protect destitute individuals against knowable threats to their lives. Since there has been no case law on this yet, it is too early to draw definite conclusions.

\section{v. Subsistence Provision}

In the cases of Nencheva and others $v$ Bulgaria and Centre of Legal Resources on behalf of Valentin Câmpeanu v Romania, which concerned threats to life stemming from, inter alia, material deprivation, the ECtHR held that the responsibility of States under Article 2 ECHR was engaged. ${ }^{115}$ The former case concerned 15 children and young people who died in a specialised public facility for mentally and physically disabled children, from the effects of cold and shortages of food, medicines and basic necessities. The director of the home had unsuccessfully tried on several occasions to alert the public institutions which had the responsibility for funding the home and which could have been expected to act. The ECtHR held that there had been a violation of Article 2 ECHR in that the relevant authorities had failed in their duty to protect the lives of the vulnerable children and young people from a serious and immediate threat. ${ }^{116}$ The ECtHR considered that the authorities should have known that there was a real risk to the lives of the children and young people, and that they had not taken the necessary protective measures within the limits of their powers. ${ }^{117}$ Critical was the fact that the children and young people in question had been entrusted to the care of the State in a specialised public facility, and that they had been, especially in the light of their vulnerability, under the exclusive supervision and control of the authorities. ${ }^{118}$

The case of Valentin Câmpeanu concerned the death of a mentally and physically ill young person in a psychiatric hospital. In this case, the ECtHR held that the domestic authorities had not provided the requisite standard of protection for Câmpeanu's life. ${ }^{119}$ The Court found, in particular, that the person in question had been placed in medical institutions that were not equipped to provide adequate care for him and his condition due to lack of heating, appropriate food, medical staff and medical resources, including medication. ${ }^{120}$ The ECtHR also noted the continuous failure of the medical staff to provide Câmpeanu with appropriate care and treatment. ${ }^{121}$ According to the ECtHR, the national authorities, despite being aware of the difficult situation in the psychiatric hospital where he had been placed, had unreasonably put his life in danger. ${ }^{122}$ In light of these considerations, the ECtHR concluded that there had been a breach of Article 2 ECHR. ${ }^{123}$

Although the ECtHR held that the responsibility of States under Article 2 ECHR was engaged in Nencheva and Câmpeanu, cases which concerned threats to life stemming from, inter alia, material deprivation, it does not necessarily follow that the ECtHR will reach the same conclusion in cases which concern threats to life stemming from destitution or lack of basic necessities. In such cases, the ECtHR might not be as willing

\footnotetext{
115 Nencheva and others v Bulgaria App no 48609/06 (ECtHR, 18 June 2013); Centre of Legal Resources on behalf of Valentin Câmpeanu v Romania App no 47848/08 (ECtHR, 17 July 2014).

116 Ibid, para 141.

117 Ibid, para 124.

118 Ibid, para 119.

119 Ibid, para 144.

120 Ibid, para 143.

121 Ibid.

122 Ibid, para 143.

123 Ibid, para 144.
} 
to hold that the responsibility of States under Article 2 ECHR is engaged as it was in Nencheva, Câmpeanu and other cases concerning threats to life, which stemmed from inadequate medical treatment in detention. ${ }^{124}$ Given that in these cases, which concern children and people who are under the exclusive control and care of the State, the State control imparts more responsibility on the States, the ECtHR is less reluctant to conclude that State responsibility is engaged than it is in cases which concern threats to the lives of the destitute or those with no means of support.

Edwards and Billings have argued that Article 2 ECHR should be interpreted as guaranteeing more than a purely mechanical physical existence. ${ }^{125}$ However, as the ECtHR emphasised in the case of Pretty $v$ the United Kingdom, Article 2 ECHR should be 'unconcerned with issues to do with the quality of living'. ${ }^{126}$ This statement demonstrates that the ECtHR is not willing to interpret Article 2 ECHR in the light of human dignity so as to read into the provision in question an obligation on States to provide the destitute or those with no means of support with the basic amenities of life. Beyond the circumstances of dependency and State control, there remain difficult questions about the extent to which States should be obliged to provide individuals with the basic necessities of life, as Palmer has observed. ${ }^{127}$ Indeed, it would have been difficult for the ECtHR to embark on these questions and to adjudicate on such cases. Despite the difficulties inherent in such cases, subsistence interests should be protected under Article 2 ECHR. Given that more people die as a result of hunger and disease than are killed, ${ }^{128}$ the right to life should guarantee health interests as well as subsistence interests, if it is to say that its provisions are practical and effective.

\section{vi. Environmental Interests}

In the case of Brincat and others $v$ Malta, which concerned a complaint about the Maltese Government's failure to protect the applicants and their deceased relative from the fatal consequences of exposure to asbestos, the ECtHR held that there had been a violation of Article 2 ECHR in respect of the applicants whose relative had died. ${ }^{129}$ The ECtHR reiterated the principles as stated in Oneryildiz. ${ }^{130}$ It considered that the positive obligation flowing from Article 2 ECHR includes a primary duty on the State to put in place a legislative and administrative framework designed to provide effective deterrence against

124 See, for instance, Salakhov and Islyamova v Ukraine App no 28005/08 (ECtHR, 14 March 2013); Jasinskis $v$ Latvia App no 45744/08 (ECtHR, 21 December 2010); Tarariyeva v Russia App no 4353/03 (ECtHR, 14 December 2006); Anguelova v Bulgaria App no 38361/97 (ECtHR, 13 June 2002); Velikova v Bulgaria App no 41488/98 (ECtHR, 18 May 2000). For a discussion of the case Tarariyeva $v$ Russia, see, Leif Scheimann, "Detainees, Medical Treatment and the European Convention on Human Rights" 13 Coventry Law Journal (2008) 38, 43.

125 Edwards and Billings, supra nt 54, 102.

126 Pretty $v$ the United Kingdom, supra nt 12, para 39.

127 Palmer, E, "Protecting Socio-Economic Rights through the European Convention on Human Rights: Trends and Developments in the European Court of Human Rights" 2 Erasmus Law Review (2009) 397, 400-401.

${ }^{128}$ Ramcharan, BG, "The Right to Life" 30 Netherlands International Law Review (1983) 297, 305. See, also, Dinstein, Y, "The Right to Life, Physical Integrity, and Liberty" in Henkin, L, (ed), The International Bill of Rights (Columbia University Press 1981), 115.

129 Brincat and others $v$ Malta Apps nos 60908/11, 62110/11, 62129/11, 62312/11 and 62338/11 (ECtHR, 24 July 2014), para 117. For a discussion of the environmental protection under Article 2 ECHR, see, Ann Sherlock and Francoise Jarvis, "The European Convention on Human Rights and the Environment" 24 (1999) European Law Review, Human Rights Survey 15, 29.

130 Brincat and others $v$ Malta, Ibid, para 101. 
threats to the right to life. ${ }^{131}$ This obligation, as the ECtHR emphasised, 'must be construed as applying in the context of any activity, whether public or not, in which the right to life may be at stake, and a fortiori in the case of industrial activities, which by their very nature are dangerous. ${ }^{132}$ In the particular context of dangerous activities, the ECtHR highlighted the need for regulations, which 'must make it compulsory for all those concerned to take practical measures to ensure the effective protection of citizens whose lives might be endangered by the inherent risks' ${ }^{133}$ The ECtHR found that the State had failed to satisfy its positive obligation to legislate or take other practical measures in order to protect the applicants from the consequences of exposure to asbestos. ${ }^{134}$

Despite the progress marked by Öneryildiz, Brincat and other similar cases (which were decided under Article 8 ECHR - the right to respect for private and family life) toward the opening up of an environmental horizon of human rights, 'they still fail to achieve the objective of the recognition of an independent right to a decent environment', as Francioni has maintained. ${ }^{135}$ As he has noted, environmental integrity is not seen as a value per se for the community affected or society as a whole, but only as a criterion to measure the negative impact on a given individual's life. ${ }^{136}$ This mainly results, as he has observed, from the ECtHR's 'purely individualistic conception of human rights' ${ }^{137}$ And indeed, in Öneryildiz and Brincat, the ECtHR focused on the consequences on the individual applicants. Nevertheless, one has to acknowledge that the ECtHR has taken a major conceptual step. It has moved far from an orthodox conception of life protection by clarifying that the protection of Article 2 ECHR might apply in cases, which concern environmental interests.

\section{B. The ICCPR}

In the ICCPR, Article 6 guarantees the right to life. ${ }^{138}$ As the HRC stated in General Comment 6 , the protection of Article 6 ICCPR requires that States adopt positive measures. ${ }^{139}$ By reading positive obligations into Article 6 ICCPR, the HRC has extended the protection of the right to life to the socio-economic arena. The HRC has interpreted Article 6 ICCPR as encompassing, in particular, subsistence interests, health interests, and interests regarding a healthy environment. This demonstrates that the integrated approach to interpretation has been put into practice by the HRC. The HRC has interpreted the traditional right to life in a progressive manner. In this way, it has permeated the provision in question with significant social and economic elements.

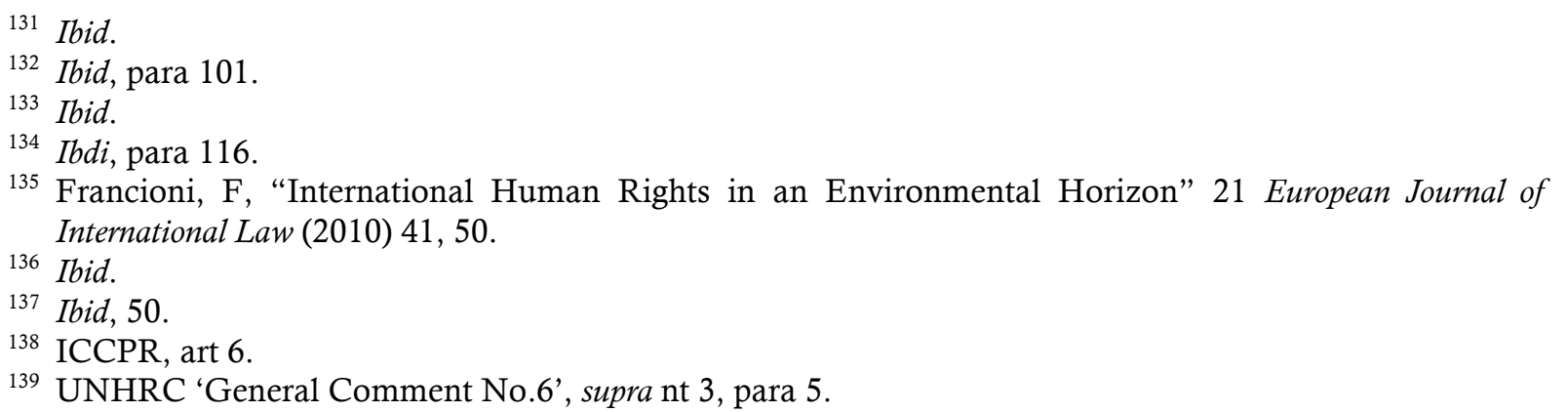




\section{i. Subsistence and Health Interests}

The HRC's use of the two techniques discussed above is especially evident in two General Comments. In General Comment 6, the HRC stated that 'it would be desirable for States parties to take all possible measures to reduce infant mortality and to increase life expectancy, especially in adopting measures to eliminate malnutrition and epidemics. ${ }^{140}$ In General Comment 6, the HRC interpreted therefore Article 6 ICCPR as encompassing subsistence and health interests. It also clarified that it would be desirable for States to take positive steps in this context. Later on, in General Comment 28, the HRC stated that it "wishes to have information on the particular impact on women of poverty and deprivation that may pose a threat to their lives. ${ }^{141}$

The HRC applied the same approach in the context of the reporting procedure. In a number of Concluding Observations, the HRC highlighted the need for adequate living conditions in prison facilities and reception facilities for asylum seekers and refugees. ${ }^{142}$ In the Concluding Observations on Canada, the HRC recommended that the State party take positive measures, as required by Article 6 ICCPR, to address homelessness, as this had led to serious health problems and even to death. ${ }^{143}$ In the Concluding Observations on Israel, the HRC stated that the State should lift its military blockade of the Gaza Strip as it had hampered people's access to all basic and life-saving services such as medical care, sufficient drinking water, adequate sanitation, food and electricity. ${ }^{144}$ The HRC also declared that the State should 'ensure that all residents of the West Bank have equal access to water, in accordance with the World Health Organization quality and quantity standards', that it should 'allow the construction of water and sanitation infrastructure, and wells', and that it should 'address the issue of sewage and waste water in the occupied territories emanating from Israel. ${ }^{, 145}$

The HRC's approach in the General Comments and Concluding Observations mentioned above leads to the conclusion that human dignity plays a crucial role in the interpretation of Article 6 ICCPR. By interpreting Article 6 ICCPR as encompassing subsistence interests, the HRC has accepted, albeit impliedly, that Article 6 ICCPR is to be interpreted in the light of human dignity, and that the right of individuals to live in a manner worthy of their dignity is protected under the provision in question. However, the HRC has not gone as far as to suggest that Article 6 ICCPR protects the right to an adequate standard of living. What the HRC has confirmed in the aforementioned General Comments and Concluding Observations is that States should provide the

${ }^{140}$ Ibid. See, also, UNHRC 'General Comment No.14', supra nt 45, para 3.

${ }^{141}$ UNHRC 'General Comment No. 28', supra nt 45, para 10.

142 See, for instance, UNHRC 'Comment on Mozambique's First Periodic Report on Implementation of the ICCPR' (19 November 2013) UN Doc CCPR/C/MOZ/CO/1, para 14; UNHRC 'Comment on Tajikistan's Second Periodic Report on Implementation of the ICCPR' (22 August 2013) UN Doc CCPR/C/TJK/CO/2, para 9; UNHRC 'Comment on Albania's Second Periodic Report on Implementation of the ICCPR' (22 August 2013) UN Doc CCPR/C/ALB/CO/2, para 13.

143 UNHRC 'Comment on Canada's Fourth Periodic Report on Implementation of the ICCPR', supra nt 45 , para 12 .

${ }^{144}$ UNHRC 'Comment on Israel's Third Periodic Report on Implementation of the ICCPR', supra nt 3, para 8; UNHRC 'Comment on Israel's Fourth Periodic Report on Implementation of the ICCPR', supra nt 3 , para 12 .

${ }^{145}$ UNHRC 'Comment on Israel's Third Periodic Report on Implementation of the ICCPR', supra nt 3, para 18. 
minimum needs for survival. ${ }^{146}$ In this way, the HRC has accepted that the right to live is envisaged as part of the right to life. ${ }^{147}$

In a number of Concluding Observations, the HRC emphasised that health interests are protected under Article 6 ICCPR. ${ }^{148}$ Regarding Uganda, for instance, the HRC expressed concerns about the inadequate access to HIV treatment, particularly antiretroviral treatment. ${ }^{199}$ Similarly, regarding Namibia, the HRC stated that the efforts of the State to combat HIV/AIDS and to provide sexual education in this regard had been inadequate. ${ }^{150}$ It stated that the State should 'pursue its efforts to protect its population from HIV/AIDS', and that it should 'adopt comprehensive measures encouraging greater numbers of persons suffering from the disease to obtain adequate antiretroviral treatment and facilitating such treatment. ${ }^{151}$ The HRC expressed concerns about the number of deaths resulting from AIDS and the unequal access to appropriate treatment for those infected with HIV in the Concluding Observations on Kenya. ${ }^{152}$

By interpreting Article 6 ICCPR in such a broad manner, the HRC has managed to furnish a positive social right encompassing health and subsistence interests. The HRC has taken 'a major conceptual step, motivated at least in part by the interdependence of human rights', as Scott has correctly observed. ${ }^{153}$ Even though this is a significant development regarding the fate of socio-economic interests under the ICCPR, the HRC's reference to 'desirability' in General Comment $6^{154}$ is a matter of concern. It indicates that States may have a 'soft law' obligation to tackle problems such as infant mortality and low life expectancy, rather than a legal 'hard law' obligation, as Joseph, Castan and Nowak have observed. ${ }^{155}$ It follows that the HRC would not necessarily hold Article 6 ICCPR to be violated when States do not create satisfactory conditions for survival.

Pessimism is also fuelled by the decision of the HRC on a communication, which concerned health interests, as it demonstrates that it is very difficult for individuals to prove that they have been victims of an Article 6 ICCPR violation. The communication

${ }^{146}$ For a discussion of the distinction between 'a basic standard of living' and 'an adequate standard of living', see, Menghistu, F, “The Satisfaction of Survival Requirements” in Ramcharan, BG, (ed), The Right to Life in International Law (Martinus Nijhoff 1985), 67.

147 Ramcharan, supra nt 128, 305.

148 See, for instance, UNHRC 'Comment on Romania's Third Periodic Report on Implementation of the ICCPR' (5 November 1993) UN Doc CCPR/C/79/Add.30, para 11; UNHRC 'Comment on Jordan's Third Periodic Report on Implementation of the ICCPR' (10 August 1994) UN Doc CCPR/C/79/Add.35, para 4; UNHRC 'Comment on Brazil's First Periodic Report on Implementation of the ICCPR' (24 July 1996) UN Doc CCPR/C/79/Add.66, para 23; UNHRC 'Comment on Nepal's First Periodic Report on Implementation of the ICCPR' (10 November 1994) UN Doc CCPR/C/79/Add.42, para 8.

149 UNHRC 'Comment on Uganda's First Periodic Report on Implementation of the ICCPR' (4 May 2004) UN Doc CCPR/CO/80/UGA, para 14. See, also, UNHRC 'Comment on Zimbabwe's First Periodic Report on Implementation of the ICCPR' (6 April 1998) UN Doc CCPR/C/79/Add.89, para 7.

150 UNHRC 'Comment on Namibia's First Periodic Report on Implementation of the ICCPR' (August 2004) UN Doc CCPR/CO/81/NAM, para 10.

151 Ibid.

${ }^{152}$ UNHRC 'Comment on Kenya's Second Periodic Report on Implementation of the ICCPR' (29 April 2005) UN Doc CCPR/CO/83/KEN, para 15.

153 Scott, supra nt 31, 877.

154 UNHRC 'General Comment No. 6', supra nt 3, para 5.

155 Joseph and Castan, supra nt 29, 203; Nowak, M, UN Covenant on Civil and Political Rights: CCPR Commentary (N P Engel 1993) 107. 
in question is Plotnikov $v$ the Russian Federation. ${ }^{156}$ This communication concerned a claim that the author's life had been put at risk because of lack of funds for medicine, caused by an indexing law which reduced the value of his savings, thus preventing him from buying medicine. The complaint was held to be inadmissible. ${ }^{157}$ The HRC noted that:

'the arguments advanced by the author [did] not substantiate, for purposes of admissibility, that the occurrence of hyperinflation or the failure of the indexing law to counterbalance the inflation would amount to a violation of any of the author's Covenant rights for which the State party can be held accountable. ${ }^{158}$

As Joseph and Castan have observed, this decision confirms that 'it will be difficult to prove that one is a victim of an [A]rticle 6 violation entailed in socio-economic deprivation. ${ }^{159}$

\section{ii. Healthy Environment}

In its Concluding Observations on Kosovo, the HRC emphasised that Article 6 ICCPR does not only protect the right to access health treatment but also the right to a healthy environment. ${ }^{160}$ The HRC entertained an individual communication based on its broad interpretation of the right to life. In EHP $v$ Canada, which concerned disposal of nuclear waste in dumpsites around Port Hope, the HRC observed that the communication 'raise[d] serious issues, with regard to the obligation of States parties to protect human life' ${ }^{161}$ The HRC therefore accepted that the right to a healthy environment might be protected under Article 6 ICCPR. Given that the exposure of the author and of other residents of Port Hope to environmental hazards posed a threat to their lives, they could legitimately claim to be victims of a potential violation of Article 6 ICCPR. The HRC, however, declared the communication inadmissible due to failure to exhaust domestic remedies. ${ }^{162}$

In another example, Dahanayake and others $v$ Sri Lanka, the authors complained that they were being deprived of a healthy environment because of the construction of an expressway road. ${ }^{163}$ The HRC held that the authors had not sufficiently substantiated their claim. ${ }^{164}$ Accordingly, the communication was declared inadmissible. ${ }^{165}$ Similarly, in Brun v France, which concerned a claim that the French decision to allow a trial for open-field testing of genetically modified organisms would breach Article 6 ICCPR, the HRC held that the author had not presented any evidence that 'the cultivation of transgenic plants in the open field represent[ed], in respect of the author, an actual violation or an imminent threat of violation of his right to life' ${ }^{166}$ The communication

156 Plotnikov $v$ the Russian Federation Communication no 784/1997, UN Doc CCPR/C/65/D/784/1997 (1999).

157 Ibid, para 5.

158 Ibid, para 4.2.

159 Joseph and Castan, supra nt 29, 206.

${ }^{160}$ UNHRC 'Comment on Kosovo's First Periodic Report on Implementation of the ICCPR' (14 August 2006) UN Doc CCPR/C/UNK/CO/1, para 14.

161 EHP v Canada Communication no 67/1980, UN Doc CCPR/C/OP/1 (1984).

162 Ibid, paras 8-9.

163 Dahanayake and others $v$ Sri Lanka Communication no 1331/2004, UN Doc CCPR/C/87/D/1331/2004 (2006).

164 Ibid, para 6.4 .

165 Ibid, para 7.

166 Brun v France Communication no 1453/2006, UN Doc CCPR/C/88/D/1453/2006 (2006), para 6.3. 
was again declared inadmissible. ${ }^{167}$ These decisions are significant because they were based on a broad interpretation of the right to life. It remains to be seen, however, whether the HRC would decide future communications based on its broad interpretation of Article 6 ICCPR. ${ }^{168}$

\section{Conclusion}

Both the ECtHR and the HRC have interpreted the right to life in a progressive and broad manner. The right to life has been permeated with significant economic and social elements. It has been interpreted, in particular, as encompassing health, subsistence and environmental interests. Both bodies therefore have made use of the integrated approach to interpretation. Both bodies have also heavily relied on the second technique - the reading of positive obligations into civil and political rights. This technique has enabled them to identify socio-economic related obligations in various contexts. However, the wording of certain General Comments, in particular General Comment 6, indicates that the obligations of States under Article 6 ICCPR may not be legal obligations, which is undoubtedly a matter of concern. The HRC has also relied, albeit indirectly, on the first technique - the interpretation of civil and political rights in the light of human dignity and has clarified that Article 6 ICCPR encompasses subsistence interests. The ECtHR, by contrast, seems unwilling to adopt the same approach, as has been demonstrated from its approach in the case law. Even though the ECtHR and the HRC have interpreted the right to life in a broad manner, the case law demonstrates that it is very difficult for individuals to succeed in their claims. This leads to the conclusion that although socioeconomic interests are protected in theory under the right to life, in practice they are not. They remain to a great extent theoretical and illusory.

167 Ibid, para 7.

168 Scott, supra nt 31, 878. 